\title{
The Existence of the Pulpit of the Historic Jakarta Mosque
}

\author{
Eksistensi Mimbar Masjid Bersejarah Jakarta
}

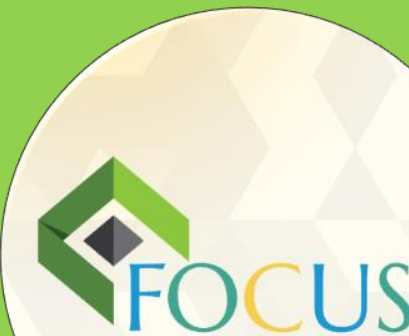 \\ Journal of Social Studies \\ Ahmad Irfan \\ Universitas Esa Unggul \\ Jakarta \\ ahmad.irfan@esaunggul.ae.id \\ Nurbaiti Bahrudin \\ Universitas Esa Unggul \\ Jakarta \\ nurbaiti@esaunggul.ac.id}

Nicky Rosadi

Universitas Indraprasta PGRI

Jakarta

nickyrosadi@gmail.com

\section{DOI}

https://doi.org/10.37010/fcs.v3i1.600

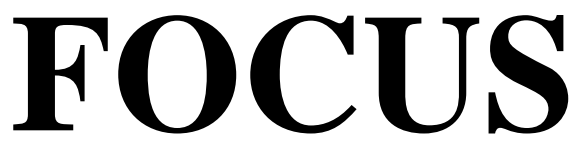

\section{Journal of Social Studies}

\section{Vol. 3 No. 1 \\ FEBRUARI \\ 2022}

Kata kunci: mimbar, masjid, Jakarta

The pulpit which existed at the time of the Prophet, then it became a sunnah that was respected, so that in generations after the Prophet the existence of the pulpit was still maintained. This study attempts to describe the existence of the pulpit at a historic mosque in Jakarta. This research uses a qualitative research approach with analytical descriptive method. The research location takes place in historic mosques in Jakarta. Data collection techniques using interviews, observation, documentation. The results of this study indicate that historic Jakarta mosques still use pulpits with various models so that their existence is still maintained today.

Keywords: pulpit, mosque, Jakarta

Abstrak

Mimbar yang keberadaannya sudah ada pada zaman Rasulullah, maka jadilah ia suatu sunah yang dihormati, sehingga pada generasi setelah Rasulullah eksistensi mimbar masih dipertahankan. Penelitian ini berupaya untuk mendeskripsikan eksistensi mimbar pada masjid bersejarah di Jakarta. Penelitian ini menggunakan pendekatan penelitian kualitatif dengan metode deskriptif analitik. Lokasi penelitian mengambil tempat di masjid-masjid bersejarah di Jakarta. Teknik pengumpulan data menggunakan wawancara, observasi, dokumentasi. Hasil penelitian ini menunjukkan bahwa masjid-masjid bersejarah Jakarta masih menggunakan mimbar dengan beragam modelnya sehingga keberadaannya masih terjaga sampai saat ini.

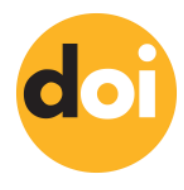




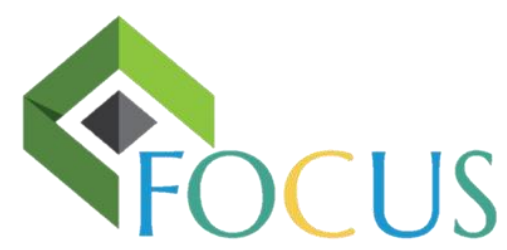

\section{PENDAHULUAN}

Masjid yang merupakan tempat sujud bagi orang muslim mempunyai peranan yang cukup strategis sebagai lembaga pembinaan umat. Sejak jaman Rasulullah masjid selain tempat untuk salat juga dipergunakan untuk berkumpul, bermusyawarah, serta pusat literasi keagamaan kaum muslimin. Dalam proses perkembangannya masjid menjadi lebih khusus sebagai bangunan tempat untuk melaksanakan salat lima waktu, Salat Jumat maupun hari raya. Pemaknaan masjid sebagai sebuah bangunan merupakan wujud dari kebudayaan Islam yang berbentuk fisik (Setiawan, 2010).

Menurut Dr. Sutjipto Wirjosuparto masjid-masjid kuno di Indonesia dimungkinkan asalnya berdasarkan bentuk bangunan pendapa atau mandapa. Mandapa menurutnya mempunyai denah yang berbentuk persegi serta dibangun di atas tanah. Bangunan mandapa yang berasal dari kebudayaan India telah dilupakan asal usulnya dan karena di saat Islam mulai berkembang di Indonesia, memerlukan bangunan masjid yang praktis untuk dijadikan masjid sehingga bentuk inilah yang dianggap paling cocok dengan kebutuhan yang diperlukan. Kemudian mengenai atap masjid yang bertingkat dasarnya sudah ada yakni pada rumah atap bertingkat berhubungan dengan estetika dalam hal mengimbangi bentuk bangunan yang besar, atapnya disusun bertingkat seperti masjid agung Surakarta dan Yogyakarta (Tjandrasasmita, 2000).

Asal pengaruh yang terjadi pada masjid masjid yang mempunyai corak atau gaya Indonesia itu terdiri dari dua pendapat pertama, pendapat yang dikemukakan oleh H.J de Graaf yakni dipengaruhi dari gaya masjid di India daerah Malabar, dan kedua bahwa gaya masjid dengan atap bertingkat berasal dari Indonesia sendiri yang merupakan tradisi seni-bangunan candi yang telah dikenal pada zaman Indonesia-Hindu sebagaimana pendapat dari G.F. Pijper dan Hidding. Pembangunan masjid dilakukan secara gotong-royong dengan arahan dari sultan atau para wali dengan ciri khas terdapat saka guru (tiang utama) dan tetap menjaga menjaga bangunan dan ukiran pada tradisi sebelum Islam dengan tujuan diantarnya adalah menarik perhatian masyarakat yang belum masuk Islam atau baru saja masuk Islam sehingga mereka senang masuk ke dalam masjid yang gayanya masih mengingatkan unsur bangunan candi. Konversi agama dari Hindu/Budha ke Islam membutuhkan penyesuaian perlahan-lahan dan penuh kebijaksanaan. (Tjandrasasmita, Pertumbuhan dan Perkembangan Kota-Kota Muslim di Indonesia dari Abad XIII sampai XVII Masehi, 2000)

Masuknya Islam ke Jakarta sangat erat kaitannya dengan aktivitas pelayaran serta perniagaan internasional di nusantara pada abad ke 13 dan 14 serta diaspora bangsa Hadrami ke Nusantara. Perkembangan Islam di Jakarta ditandai dengan berdirinya masjid-masjid sejak abad ke 16 dan makin berkembang pada abad berikutnya mulai dari daerah pesisir, sampai ke daerah pedalaman, untuk saat ini masjid-masjid tersebut ada beberapa elemennya mengalami perubahan fisik baik faktor pemugaran maupun perluasan. (Chair, 1995) di antara elemen masjid yang sangat penting dalam proses berjalannya ibadah di dalam masjid selain dari menara, mihrab, kolam adalah mimbar khotbah. Penggunaan mimbar yang memang sudah ada sejak jaman Rasulullah dan menjadi sunah dalam penggunaannya sebagai tempat menyampaikan khotbah (Khalis, 2012).

Sebelum kedatangan Islam masyarakat Arab sudah mempunyai suatu kebiasaan tatkala berbicara mereka berdiri di atas lantai bertumpu pada sepotong panah atau tombak dan juga terkadang di atas kuda, kedua cara ini pernah dilakukan Nabi Muhammad saat berkhotbah. Di Arafah, Rasulullah SAW pernah berkhotbah di atas untanya di hadapan orang banyak. Jika nabi berkhotbah di Madinah pada hari Jumat beliau bersandar atau berdiri berpegang pada pohon kurma yang menjadi tiang masjid. Mimbarnya sangat sederhana terdiri dari tiga tangga batang kayu. Beliau berdiri di atas tangga yang ketiga, kadang bertopang dengan panah atau pedang. Mimbar digunakan untuk berkhotbah dengan tujuan agar khotbah dapat diperdengarkan orang banyak yang hadir. Hadis dari Ibn Asir menerankan bahwa sahabat-sahabat pernah meminta Rasulullah untuk mengambil tempat duduk di mimbar ketika menemui utusan-utusan yang datang menghadapnya. Keterangan ini dikuatkan pula dengan hadis lain, bahwa nabi tatkala dikunjungi oleh seorang bernama Tamim beliau duduk di atas mimbar dan berbicara dengan orang itu dari atas mimbar. Dari peristiwa itu mimbar juga menggambarkan kedudukan dan jabatan kepala negara. Nabi juga menggunakan mimbar saat mengajar, menyiarkan dan menyampaikan pengumumanpengumuman penting. Mimbar nabi yang pertama dinamakan A'wad, dari nama bahan kayu yang dipakai untuk mimbar itu (Atjeh, 1955). 
Mimbar biasanya diletakkan pada sebelah kanan mihrab dan memiliki anak tangga dan umumnya memiliki atap berbentuk cupola. Islam memerintahkan untuk membangun masjid akan tetapi tidak membakukan bentuk bangunannya, sehingga umat Islam memiliki kebebasan dalam membangunnya, sehingga masjid dan segala elemennya termasuk mimbar adalah wujud dari kebudayaan yang ada. Mimbar yang keberadaannya sudah ada pada zaman Rasulullah, maka jadilah ia suatu sunah yang dihormati sehingga pada generasi setelah Rasulullah eksisitensi mimbar masih dipertahankan. Oleh sebab itu, penelitian ini berupaya untuk mendeskripsikan eksistensi mimbar pada masjid bersejarah di Jakarta.

\section{METODE}

Penelitian ini menggunakan pendekatan penelitian Kualitatif dengan metode deskriptif analistik dengan tujuan untuk menemukan dan menggambarkan bentuk-bentuk dan posisi mimbar masjid bersejarah di Jakarta sekitar abad 18 s.d. abad 20. Data primer penelitian ini di dapatkan langsung dari para pengurus DKM Masjid, sejarawan dan tokoh masyarakat yang dilakukan melalui wawancara, observasi sedangkan data sekunder didapatkan melalui kepustakaan berupa buku-buku, karya ilmiah maupun media online. Lokasi penelitian mengambil tempat di masjid-masjid bersejarah di Jakarta. Teknik pengumpulan data menggunakan wawancara, observasi, dokumentasi. Sedangkan teknik analisis data melalui tahapan reduksi data, penyajian data dan pengambilan simpulan.

\section{HASIL DAN PEMBAHASAN}

\section{Hasil}

Berdasarkan hasil pengumpulan data di lapangan maka ditemukan dalam penelitian terhadap masjid-masjid bersejarah di Jakarta pada buku terbitan Erlangga yang berjudul Masjid-Masjid Bersejarah di Jakarta Tahun 2010 yang di dalamnya terdapat kata sambutan oleh Gubernur DKI Jakarta saat itu Bapak. Fauzi Bowo mewakili Pemprov DKI Jakarta. Dalam buku tersebut bersifat umum membahas masjid dari sisi sejarah serta elemenelemen di dalam masjid akan tetapi tidak memfokuskan pada pembahasan mimbar masjid-masjid bersejarah. Buku tersebut dijadikan peneliti sebagai data dari kajian terdahulu.

Peneliti melakukan eksplorasi ke masjid-masjid bersejarah di 5 (lima) Wilayah Kotamadya DKI Jakarta yang masih menggunakan mimbar. Persebaran masjid-masjid bersejarah di Jakarta berdasarkan buku terbitan Erlangga yang berjudul Masjid-Masjid Bersejarah di Jakarta Tahun 2010 ditemukan 19 (Sembilan belas) masjid bersejarah dengan sebaran pada wilayah Jakarta Barat 8 (delapan) masjid, Jakarta Selatan 1 (satu) masjid, Jakarta Pusat 5 (Lima) masjid, Jakarta Utara 4 (empat) masjid, Jakarta Timur 1 (satu) masjid.

Berdasarkan observasi lapangan didapatkan gambaran bentuk dan posisi mimbar dalam masjid-masjid bersejarah di Jakarta dijelaskan dalam tabel di bawah ini.

Tabel 1. Masjid bersejarah di Jakarta yang menggunakan mimbar

\begin{tabular}{|c|c|c|c|c|c|}
\hline \multirow{2}{*}{ No. } & \multirow{2}{*}{ Masjid } & \multirow{2}{*}{\multicolumn{2}{|c|}{ Alamat }} & \multicolumn{2}{|l|}{ Mimbar } \\
\hline & & & & Bentuk & Posisi \\
\hline 1. & $\begin{array}{l}\text { Al Alam Cilincing } \\
(1655 \mathrm{M})\end{array}$ & $\begin{array}{l}\text { Pantai Cilincing, } \\
\text { Utara }\end{array}$ & Jakarta & $\begin{array}{l}\text { Bagian kanan, kiri, belakang, dan atas } \\
\text { tertutup, bagian depan terdapat } \\
\text { kaligrafi kalimat tauhid, dan terdapat } \\
2 \text { anak tangga pada mimbar. Mimbar } \\
\text { terbuat dari beton }\end{array}$ & $\begin{array}{l}\text { Posisi mimbar di luar } \\
\text { mihrab sebelah kanan. } \\
\text { (dalam pandangan } \\
\text { mengarah r ke } \\
\text { kiblat/barat) }\end{array}$ \\
\hline 2. & $\begin{array}{l}\text { As Salafiyah } \\
(1620 \mathrm{M})\end{array}$ & $\begin{array}{l}\text { J1. Jatinegara } \\
\text { Raya } \quad \text { No.2B }\end{array}$ & $\begin{array}{r}\text { Kaum } \\
\text { Kel. }\end{array}$ & $\begin{array}{l}\text { Bagian kanan dan kiri mimbar } \\
\text { terbuka setengah bagian, bagian atas } \\
\text { mimbar tertutup, bagian belakang }\end{array}$ & $\begin{array}{l}\text { Posisi mimbar di } \\
\text { sebelah kanan mihrab. }\end{array}$ \\
\hline
\end{tabular}


Jatinegara Kaum, mimbar terbuka setengah bagian, dan

Jakarta Timur terdapat 3 anak tangga pada mimbar.

Mimbar terbuat dari kayu jati

Bagian kanan dan kiri mimbar terbuka setengah bagian, bagian atas

J1. Pengukiran II, Kel. mimbar tertutup, bagian belakang Pekojan, Kec.Pekojan mimbar terbuka setengah bagian, dan

3. $\mathrm{Al}$ Anshar Jakarta Barat

(1648) terdapat 3 anak tangga pada mimbar. Pada bagian depan atas mimbar terdapat ukiran. Mimbar terbuat dari kayu jati.

Bagian kanan mimbar tertutup dan kiri terdapat lubang angin, bagian atas Kampung Marunda Besar, Kel. Marunda,

4. Al Alam Marunda (1663M)

Kec. Cilincing, Jakarta Utara

tertutup, bagian belakang tertutup dan terdapat lubang angin, terdapat 3 anak bagian belakang mimbar tertutup,
J1. Luar Batang V No. 1 Kampung Luar Batang,

6. Luar Batang (1739)

Al Mansh
$(1717 \mathrm{M})$

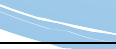

7. Kampung

(Bandengan)

(1743M)

Baru Jl. Bandengan Selatan, Jakarta Barat Jakarta Utara
8. An Nawier Pekojan

J1. Pekojan No.79

$\begin{array}{lll}\text { 9. Jami Tambora } & \text { J1. Tambora } & \text { No.11 } \\ (1760 \mathrm{M}) & \text { Jakarta Barat } & \end{array}$

10. $\mathrm{Al}$ Anwar (Angke) (1761M)

Jl. Tubagus Angke. Kel. Angke, Kec. Tambora Jakarta Barat

Jl. Hayam Wuruk No.85, Taman Sari, Jakarta Barat

\section{Jami Kebon Jeruk (1786M)}

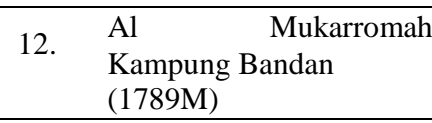

Jl.Lodan raya, kampung Bandan, Kel.Ancol, tangga, dan bagian depan atas mimbar terdapat bacaan wa'bud rabbaka hatta ya'ti kalyaqin. Mimbar terbuat dari beton

Bagian kanan kiri mimbar tertutup, bagian atas tertutup, dan terdapat dua anak tangga pada mimbar. Pada bagian atas mimbar terdapat tulisan hadza min fadhli robbi. Mimbar terbuat dari beton

Bagian kanan, kiri, dan belakang mimbar terbuka sebagian, bagian atas tertutup, terdapat dua anak tangga. Mimbar terbuat dari kayu jati.

Bagian kanan dan kiri mimbar tertutup, bagian belakang mimbar terdapat lubang angin, bagian atas tertutup, dan mimbar memiliki dua anak tangga. Mimbar terbuat dari beton.

Kanan dan kiri terdapat ukiran

kembang, atas tertutup , terdapat empat anak tangga. Pada bagian belakang tertutup dan bagian depan mimbar berbentuk seperti gerbang lengkap dengan gapura di atasnya.

Bagian kanan dan kiri mimbar

terbuka setengah bagian, dan bagian belakang mimbar tertutup, bagian atas terbuka, dan terdapat 3 anak bangga. Terbuat dari kayu jati.

Posisi mimbar di sebelah kanan mihrab

Posisi mimbar di luar mihrab sebelah kanan

Posisi mimbar di luar mihrab sebelah kanan.

Posisi mimbar di dalam mihrab.

Posisi di luar mihrab sebelah kanan.

Di luar mihrab sebelah kanan

Posisi di dalam mihrab sebelah kanan.

Bagian kanan dan kiri mimbar tertutup, bagian belakang dan atas tertutup, dan terdapat 4 anak tangga. Mimbar terbuat dari beton.

Bagian kanan, kiri, belakang, dan atas mimbar terbuka, dan mimbar memiliki 3 anak tangga. Terbuat dari kayu jati.

Bagian kanan dan kiri mimbar Posisi di dalam mihrab

terbuka sebagian, bagian belakang sebelah kanan. mimbar terbuka, bagian atas tertutup,
Posisi di luar mihrab sebelah kanan.

Posisi mimbar di dalam mihrab sebelah kanan. 
Kec. Pademangan, dan bagian depan tertutup (masuk Jakarta Utara

mimbar melalui bagian mimbar sebelah kanan), dan mimbar memiliki dua anak tangga. Terbuat dari kayu jati.

Bagian kanan, kiri, dan belakang mimbar terdapat lubang angin, bagian atas tertutup, dan bagian depan terdapat tiang semu (terdapat hiasan seperti bentuk kubah). Terdapat 3 anak tangga akan tetapi sudah terkubur tanah, sisa 1 anak tangga pada mimbar. Mimbar terbuat dari beton. (mimbar ini sudah tidak terpakai di karena masjid mengalami perluasan) dan digantikan dengan mimbar kayu jati dengan 2 anak tangga

Bagian kanan dan kiri mimbar terbuka setengah bagian, bagian

14. At Taibin (1815M)

J1.Senen Raya No.4, Kalileo, Senen Jakarta Pusat

belakang tertutup (terdapat lubang angin), bagian atas tertutup, dan terdapat 3 anak tangga pada mimbar. Mimbar terbuat dari beton (mimbar dibingkai ukiran kayu jati bertuliskan ayat kursi)

Bagian kanan, kiri, dan belakang mimbar terdapat lubang angin. Bagian depan atas terdapat inkripsi

15. Langgar Tinggi (1829M)
Jl. Pekojan Raya No.43 Jakarta Barat bahasa Arab di atas mimbar kayu berukir memohon doa kepada Allah untuk Syekh Said bin Salim Naum penyumbang mimbar. Terdapat 1 anak tangga. Mimbar terbuat dari kayu jati.

Masjid ini tidak menggunakan mimbar dengan anak tangga, akan tetapi menggunakan Podium sejak 1989

Bagian kanan dan kiri terdapat ukiran mimbar bermotif flora dan fauna,

Jl. Masjid Hidayatullah, bagian belakang mimbar tertutup

17. Hidayatullah (Abad 20)

Kel. Karet Semanggi, Kec. Setia Budi, Jakarta Selatan

terdapat inskripsi Arab Melayu yang menyatakan masjid ini dipugar dua kali tahun 1921 dan 1948, bagian atas tertutup, dan terdapat 3 anak tangga pada mimbar. Mimbar terbuat dari kayu jati.

Bagian kanan dan kiri mimbar terbuka setengah bagian, bagian J1. Raden Saleh No.30 belakang terbuka sebagian, dan pada
Kel. Cikini, Kec. $\quad$ bagian atas mimbar tertutup (terdapat $\begin{array}{ll}\text { Kel. Cikini, Kec. } & \text { bagian atas mimbar tertutup (terdapat } \\ \text { Menteng, Jakarta Pusat lambang bulan bintang), bagian }\end{array}$ depan atas mimbar terdapat ukiran flora. Terdapat dua anak tangga. Mimbar terbuat dari kayu jati.

\section{Istiqlal} (1961M)
J1. Pintu Air Kec. Sawah Besar, Jakarta Pusat
Mimbar terbuat dari beton dengan 15 anak tangga
Posisi mimbar di luar mihrab sebelah kanan.

Posisi mimbar di dalam mihrab di sebelah kanan.

Posisi mimbar di luar mihrab sebelah kanan.

Posisi podium terdapat di luar mihrab

Posisi mimbar di luar sebelah kanan mimbar.

Posisi mimbar di tengah mihrab.

Posisi terdapat di dalam mihrab sebelah kanan atas 


\section{Pembahasan}

Masjid-masjid kuno di Indonesia pada dasarnya dibangun berdasarkan tradisi seni bangunan lama, baik dari tradisi seni bangunan kayu maupun batu bata alam. Hal yang paling menonjol dalam bangunan masjid kuno di Indonesia dan Jakarta adalah struktur tersusun yakni sistem saling menumpang tiga unsur konstruksi yang meliputi bagian bawah terbuat dari batu beton sebagai konstruksi pengantar beban ke tanah. Tiang soko guru dan tiang-tiang lainnya berdiri di atas umpak pada fondasi. Atap umumnya bersusun ganjil, saling menumpang dan membentuk limasan dan untuk tembok atau pagar keliling masjid terbuat dari batu bata dengan teknik susun yang pernah dipakai bangunan candi zaman Hindu. (Ambary, 1998)

Pada dasarnya keberadaan mimbar atau mimbar sudah ada sejak jaman Rasulullah Saw. mimbar dapat berarti tempat duduk, kursi, tahta. Untuk saat ini mimbar dipakai untuk tempat berbicara, tempat berkhotbah pada hari Jumat. Di antara sunah-sunah khotbah adalah menyampaikannya di atas mimbar atau jika ketiadaan mimbar menyampaikan khotbah pada tempat yang lebih tinggi serta disunahkan mengucapkan salam ketika hendak menuju mimbar, menaiki anak tangga mimbar, dan ketika menghadap jamaah. Posisi mimbar pun disunahkan diletakkan di samping kanan mihrab (Hadrami, 2019). Bentuk inti mimbar adalah tempat khotbah yang terdiri dari anak tangga sehingga menjadikan posisi khatib lebih tinggi dari jamaah mempunyai keragaman bentuk termasuk posisi pintu masuk mimbar, di antara keragaman pintu masuk mimbar ada yang dari depan, samping dan dari belakang (Yusuf, 2020).

Menurut Koentraningrat bahwa wujud kebudayaan terbagi menjadi tiga, yaitu pertama sebagai suatu kompleks ide, gagasan, nilai, norma, peraturan, kedua sebagai suatu kompleks aktivitas serta tindakan perilaku manusia, ketiga sebagai benda-benda hasil karya manusia. (Koentjaraningrat, 2009) Dalam konteks penelitian ini adalah bahwa mimbar masjid bersejarah Jakarta merupakan wujud dari kebudayaan fisik hasil dari aktivitas karya manusia di masyarakat. Berdasarkan pengamatan peneliti bahwa mimbar masjid di Jakarta masih banyak yang terjaga baik dalam aspek keaslian maupun aspek penggunaan yang tetap eksis dibandingkan dengan podium yang cenderung tidak menggunakan anak. Tidak banyaknya perubahan pada elemen-elemen masjid juga disampaikan dalam penelitian Widya Katarina (Katarina, 2012).

Mimbar dalam kamus Misbahul Munir, sebuah kamus yang dirujuk dalam kitab-kitab fiqih mendefinisikan mimbar sebagai Kullu sya'in Rufi'a fa qod Nubira wa minhu al minbaru liirtifaa 'ihi yang artinya adalah setiap sesuatu yang diangkat disebut dengan mimbar karena ketinggiannya, sehingga mimbar merupakan bagian dari alat atau tempat yang tinggi untuk berpidato (Fayyumi, 2003). Mengacu pada definisi mimbar tersebut maka eksistensi mimbar di masjid-masjid bersejarah Jakarta masih sangat terjaga, hal ini dibuktikan dalam observasi di lapangan bahwa dari 19 masjid bersejarah ditemukan hanya 1 masjid saya yang menggunakan Podium (tempat berpidato yang tidak tinggi) yakni pada masjid Cut Meutia.

\section{PENUTUP}

Temuan pada penelitian eksistensi mimbar masjid-masjid bersejarah Jakarta bahwa dari 19 Masjid bersejarah berdasarkan penelitian terdahulu yang tercantum pada buku Masjid-masjid bersejarah Jakarta terbitan Erlangga bahwa terdapat 18 masjid yang masih menggunakan mimbar baik yang seumur dengan masjidnya maupun yang menggunakan mimbar yang baru, di antara masjid yang menggunakan mimbar yang baru adalah (1) Masjid al Mukarromah Kampung Bandan, (2) Masjid Mangga Dua, (3) Masjid Tambora, (4) Masjid Al Anshar. Sedang terdapat 1 masjid saya yang menggunakan Podium (tempat berpidato yang tidak tinggi) yakni pada masjid Cut Meutia.

Pada beberapa mimbar di masjid bersejarah di Jakarta sangat beragam bentuknya baik dari jumlah anak tangga, atap penutup mimbar maupun bahan dasar pembuatan mimbar. Hasil dari penelitian ini perlu 

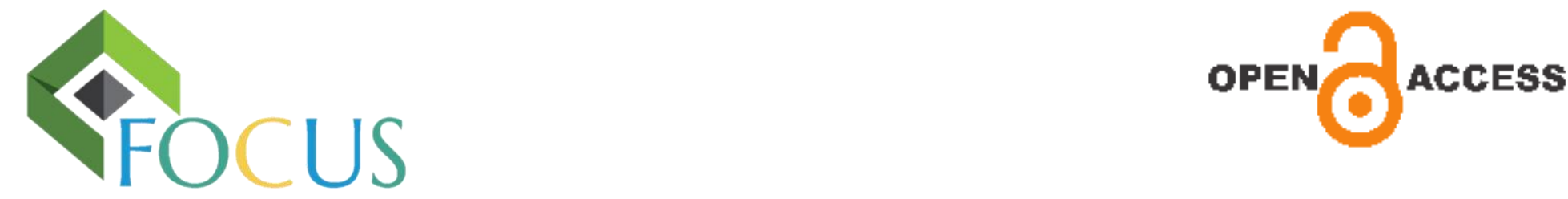

dikembangkan pada penelitian lanjutan yang juga di harapkan penelitian berikutnya memperbaiki temuan ini jika terdapat kekeliruan.

\section{DAFTAR PUSTAKA}

Ambary, H. M. (1998). Menemukan Peradaban Jejak Arkeologis dan Historis Islam Indonesia. Jakarta: Logos.

Atjeh, A. B. (1955). Sedjarah Mesjid dan amal ibadah dalamnja. Banjarmasin: Fa Toko Buku Adil.

Chair, A. (1995). Sunda Kelapa Sebagai Bandar Jalur Sutra (Masjid-Masjid Lama di Jakarta Sampai Abad ke 18). Jakarta: Dwi Jaya Karya.

Fayyumi, A. b. (2003). al Misbahul Munir. Mesir: Darul Hadis.

Hadrami, S. b. (2019). Busyrol Karim Bi Syarhi Masail at Ta'lim. Beirut: Darul Kutub Ilmiyyah.

Katarina, W. (2012). Studi Bentuk dan Elemen Arsitektur Masjid di Jakarta dari Abad 18 - Abad 20. Katarina, W. (2012). Studi Bentuk dan Elemen Arsitektur Masjid di Jakarta dari Abad 18-Abad 20. ComTech: Computer, Mathematics and Engineering Applications, 3(2), 917-927., 917-927.

Khalis, N. (2012). Mimbar dan Podium: Kajian atas Masjid Kuno di Nagroe Aceh Darussalam. Jurnal Lektur Keagamaan, Kholis, N. (2012). Mimbar dan Podium: Kajian atas Masjid Kuno di Nanggroe Aceh Darussalam. Jurnal Lektur Keagamaan, 10(2), 431-446.

Koentjaraningrat. (2009). Pengantar Ilmu Antropologi. Jakarta: Rineka Cipta.

Setiawan, K. (2010). Masjid Masjid Bersejarah di Jakarta. Jakarta: Erlangga .

Tjandrasasmita, U. (2000). Penelitian Arkeologi Islam di Indonesia dari Masa ke Masa. Kudus: Menara Kudus.

Tjandrasasmita, U. (2000). Pertumbuhan dan Perkembangan Kota-Kota Muslim di Indonesia dari Abad XIII sampai XVII Masehi. Kudus: Menara Kudus.

Yusuf, A. F. (2020). A Study of Mosque Mimbar Entrance. Yusof, A. F., Nordin, T. E., Zaki, M. Z. M., \& Samsudin, N. S. (2020). A Study of Mosque Mimbar Entrance. Jurnal Islam dan Masyarakat Kontemporari, 21(2), 102-115., 102. 